\title{
Selection of parents and segregating populations of black bean resistant to fusarium wilt with high yield and seed weight
}

\author{
D.G. Pereira ${ }^{1}$, L.C. Faria ${ }^{2}$, T.L.P.O. Souza ${ }^{2}$, L.C. Melo ${ }^{2}$ and H.S. Pereira ${ }^{2}$ \\ ${ }^{1}$ Universidade Federal de Goiás, Goiânia, GO, Brasil \\ ${ }^{2}$ Embrapa Arroz e Feijão, Santo Antônio de Goiás, GO, Brasil \\ Corresponding author: H.S. Pereira \\ E-mail: helton.pereira@embrapa.br \\ Genet. Mol. Res. 18 (3): gmr18276 \\ Received February 22, 2018 \\ Accepted July 01, 2019 \\ Published July 12, 2019 \\ DOI http://dx.doi.org/10.4238/gmr18276
}

\begin{abstract}
Diallel analysis and field tests have not been used in selecting for resistance to fusarium wilt in common beans (dry beans, Phaseolus vulgaris). Our goal was to select parents and segregating populations of dry bean (common bean) with black seed coat that are resistant to fusarium wilt and have high yield and high seed weight. Eight common bean cultivars and elite lines with some level of resistance to fusarium wilt based on previous evaluations, were used to make crosses in a complete diallel scheme. The 28 populations obtained were evaluated with two controls in trials in the $F_{3}$ (winter/2012), $\mathrm{F}_{4}$ (winter/2013), and $\mathrm{F}_{5}$ (winter/2014) generations in randomized blocks, with three replications, in plots of two 4-meter rows. The trials were conducted in Santo Antônio de Goiás, GO, Brazil, in a field infested by Fusarium oxysporum $f$. sp. phaseoli in the winter growing season. Data were obtained on reaction to fusarium wilt, yield, and 100 seed weight. Individual and joint analyses of variance and diallel analysis were conducted on these data regarding reaction to fusarium wilt. Mean values were clustered using the Scott-Knott test. Genetic variability was detected for the three traits. There were significant differences among the general combining abilities of the parents and specific combining abilities of the populations for reaction to fusarium wilt, and the additive and non-additive effects were significant. The CNFP 15867 line is
\end{abstract}


recommended for performing new crosses, because it exhibited a positive estimate of general combining ability (0.39), which indicates that it contributes to obtaining more resistant populations. The populations BRS Esplendor $\mathrm{x}$ BRS Expedito and BRS Expedito $\mathrm{x}$ CNFP 15867 were the most promising for extraction of lines, because they present high resistance to fusarium wilt (-2.6 and -2.8) and high grain yield (2212 and $\left.2270 \mathrm{~kg} \cdot \mathrm{ha}^{-1}\right)$, and acceptable seed weight (21.1 and $20.5 \mathrm{~g} / 100$ grains).

Key words: Phaseolus vulgaris; Fusarium oxysporum f. sp. phaseoli; Diallel

\section{INTRODUCTION}

Dry bean (common bean) yield can be limited by various diseases; one of the main diseases being fusarium wilt, caused by Fusarium oxysporum $f$. sp. phaseoli. This disease results in lower crop yield (Souza et al., 2012). It is found throughout the Brazilian territory, especially in regions where common beans are grown under center pivot irrigation systems, due to consecutive common bean crops in the same area, which hinders control through the use of crop rotation practices (Costa et al., 2007). The most effective measure for control of this disease is the use of resistant cultivars, together with integrated management. The use of resistant cultivars is a low cost technology that is highly effective and easily adopted by farmers. It also reduces environmental pollution through reducing the use of agricultural chemicals.

Beans of types carioca and black are the most important in Brazil, representing respectively 70 and $20 \%$ of the national production, which is about 2.5 million tons (Souza et al., 2013). However, most Brazilian cultivars of common bean in these market classes are susceptible to fusarium wilt. Thus, the development of new cultivars with resistance to this pathogen is important.

For a cultivar to be widely adopted by producers, it must also be high yielding and have commercial size bean grains, because these traits are of great commercial importance. Because of this, these traits must be considered from the initial stages of the breeding program (Mendes et al., 2009).

In programs for breeding disease-resistant plants, it is necessary to know the variability of the pathogen, identify sources of resistance, and obtain segregating populations for later development of lines. The use of diallel crosses has proven to be suitable in meeting the requirement of obtaining segregating populations in an efficient manner, because it allows parents to be selected based on their genetic values (Ramalho et al., 2005). Diallel crosses allow recombination of existing genetic variability so as to produce superior cultivars. One of the methods of diallel cross analysis is that presented by Griffing (1956), through which the effects of general combining ability and specific combining ability are estimated (Ramalho et al., 2005). This type of analysis has been used for various traits in common bean, such as seed yield (Mendes et al., 2009), early maturity (Vale et al., 2015), reaction to fusarium wilt (Batista et al., 2016), reaction to white mold (Ferreira et al., 2018), and drought tolerance (Gonçalves et al., 2015), among others. However, reports of its use for reaction to fusarium wilt in field conditions were not found. Most studies published related to breeding of common bean for resistance to fusarium wilt 
have been conducted under controlled conditions and, thus, reports regarding evaluation of genotypes under the conditions of fields infested by the pathogen are rare, even though this procedure is indispensable for obtaining resistant cultivars.

Thus, the aims of this study were to obtain and select segregating populations of black beans with resistance to fusarium wilt, high yield, and large bean grain size; to study genetic control of resistance; and to select parents with resistance to fusarium wilt, based on diallel analysis.

\section{MATERIAL AND METHODS}

The segregating populations used were obtained from crosses made in a complete diallel scheme without reciprocals, according to the method proposed by Griffing (1956). Eight lines/cultivars of black beans were crossed. The parents used were the cultivars BRS Esplendor, BRS Campeiro, and BRS Expedito (Pereira et al., 2014) and the pre-commercial lines CNFP 15867, CNFP 15868, CNFP 15869, CNFP 15870, and CNFP 15871 (Rava et al., 1996). These lines are resistant to fusarium wilt under controlled conditions, when inoculated with the isolate FOP 46, and also show good resistance in the field (Gonçalves, 2016). These parents have different crosses of origin, different levels of resistance to fusarium wilt, and also differences in other traits of agronomic importance, such as yield potential and bean grain size (Pereira et al., 2014; Gonçalves, 2016).

The crosses were made in Santo Antônio de Goiás, GO, under greenhouse conditions, as well as the advance of the $F_{1}$ generation. The advance of the $F_{2}$ generation was in the field, in a pathogen-free area in the winter crop season in 2011. Beginning at that point, the $\mathrm{F}_{3}, \mathrm{~F}_{4}$, and $\mathrm{F}_{5}$ generations were evaluated, also in Santo Antônio de Goiás, in the winter/2012 $\left(\mathrm{F}_{3}\right)$, winter/2013 $\left(\mathrm{F}_{4}\right)$, and winter/2014 $\left(\mathrm{F}_{5}\right)$ crop seasons, respectively, with center pivot irrigation. The area used for sowing is infested by the pathogen and had already been used for evaluation of the reaction of common bean lines/cultivars to fusarium wilt in other studies (Costa et al., 2011; Pereira et al., 2014, 2018; Melo et al., 2017).

The trials were composed by the 28 populations obtained in the crosses plus two controls: BRS Supremo, susceptible to fusarium wilt (Pereira et al., 2012); and BRS Esplendor, resistant to fusarium wilt and a standard for agronomic traits (Costa et al., 2011). The trials were set up in randomized blocks with three replications, and plots consisted of two 4-meter-length rows, at a spacing of $0.45 \mathrm{~m}$.

The reaction to fusarium wilt, seed yield, and 100 seed weight were evaluated. The reaction to fusarium wilt was evaluated by two evaluators based on natural occurrence of the disease, using a scoring scale proposed by the International Center for Tropical Agriculture (CIAT) and described by Pastor-Corrales \& Schoonhoven (1987), with values ranging from 1 (totally resistant plants) to 9 (susceptible plants, dead). For evaluation of seed yield, in $\mathrm{kg} \mathrm{ha}^{-1}$, two rows were harvested from each one of the plots. One hundred seed weight was determined from a random sample of 100 seeds from each plot, which was subsequently weighed. After obtaining the data, analyses of variance were performed for each trait in each one of the experiments. Joint analyses of variance were also performed, and then the test of homogeneity of variances using the ratio between the highest residual mean square and the lowest residual mean square. Values greater than seven for this ratio indicate non-homogeneous variances. When this occurred, an adjustment was made in the degrees of freedom (Pimentel-Gomes, 2000; Cochran, 1954). 
Selective accuracy (SA) was determined to evaluate the informativity of the experiments, as proposed by Rezende \& Duarte (2007). The contribution of each source of variation to total variation in combined analysis was also estimated, using the estimate of the coefficient of determination $\left(\mathrm{R}^{2}\right)$ for each one of the traits, also for diallel analysis (Ramalho et al., 1998). Contrasts among means were compared by the Scott-Knott (1974) test at $10 \%$ probability to decrease the likelihood of absence of discrimination between treatments due to type II error. According to Zimmerman (2014), this level of significance is used when small differences are expected among treatments.

For reaction to fusarium wilt, diallel analysis was also carried out using method IV proposed by Griffing (1956). To do so, the scores were inverted, such that score 9 was equivalent to the best genotype and 1 to the most susceptible. The effects of general combining ability (GCA) and specific combining ability (SCA) were estimated, as well as the variances of the effects and of the contrasts between the GCA and SCA effects, when they were significant (Cruz et al., 2012). Analyses were processed with the assistance of the Genes program (Cruz, 2013).

\section{RESULTS AND DISCUSSION}

Considering each generation for reaction to fusarium wilt, the experimental coefficients of variation (CV) ranged from $20.3 \%$ to $29.4 \%$ and indicated good experimental accuracy, considering that the disease was evaluated in the field (Table 1) (Cândida et al., 2009). The estimates of selective accuracy (SA) were considered high $(0.70$ $\leq \mathrm{SA}<0.90)$ in the $\mathrm{F}_{3}$ and $\mathrm{F}_{4}$ generations and moderate $(0.50 \leq \mathrm{SA}<0.70)$ in the $\mathrm{F}_{5}$ generation, indicating good informativity of the experiments. There were significant differences for reaction to fusarium wilt in the three generations, indicating that there is genetic variability among the treatments evaluated. There were also significant differences among the controls in the three years of evaluation, confirming the large contrast between the highly susceptible control (BRS Supremo) and the other highly resistant control (BRS Esplendor) (Pereira et al. 2014). Among the populations, there was a significant effect only in the $F_{4}$ generation, indicating greater genetic variability among the populations in that generation.

Considering joint analysis, there was significant difference among the treatments, among populations, and between controls, confirming genetic variability among the populations, which allows selection of the most resistant plants (Table 1). There was also a significant difference among the years/generations (YG), indicating that the YG affected the mean values of the genotypes. That may be explained by the differences in the climate conditions in the three years. It is common for the effect of years to be important in evaluation of diseases (Pereira et al., 2018). Another explanation may be the increase in the level of resistance of the populations through the effect of natural selection, due to the increase in homozygosity, as already commented.

Decomposition of the interaction between treatments and years/generations in populations $\mathrm{x}$ years/generations $(\mathrm{P} \times \mathrm{YG})$ and controls $\mathrm{x}$ years/generations $(\mathrm{C} \times \mathrm{YG})$ did not show significant interactions, which indicates that the best populations and the best controls remained the same, regardless of the YG (Table 1). In the case of the controls, the YG effect is exclusively due to the years factor, indicating that there were environmental differences (climate, water availability, etc.) since the controls are lines, which are homogeneous, in 
which there is no effect of generations. Thus, the lack of interaction indicates that the area used is quite homogeneous regarding distribution of inoculum, and possibly with the occurrence of the same races of Fusarium oxysporum $f$. sp. phaseoli in the three years of evaluation. Observing the importance of each source of variation through the estimates of $\mathrm{R}^{2}, 47 \%$ of the total variation was due to genetic variability among the treatments, which confirms the considerable importance of the genetic effects. The effect of years/generations, for its part, exhibited little importance (4\%).

Table 1. Summary of the individual and joint analyses of variance for reaction to fusarium wilt in the winter/2012 $\left(\mathrm{F}_{3}\right)$, winter/2013 $\left(\mathrm{F}_{4}\right)$, and winter/2014 $\left(\mathrm{F}_{5}\right)$ crop seasons evaluated in segregating populations of black bean in Santo Antônio de Goiás, GO, Brazil.

\begin{tabular}{|c|c|c|c|c|c|c|c|c|c|c|c|}
\hline \multirow{2}{*}{ Source of Variation } & \multicolumn{3}{|c|}{$\mathbf{F}_{3}$} & \multicolumn{2}{|c|}{$\mathbf{F}_{4}$} & \multicolumn{2}{|c|}{$\overline{\mathbf{F}_{5}}$} & \multicolumn{4}{|c|}{ Joint } \\
\hline & $\mathrm{DF}^{1}$ & $\mathbf{M S}^{2}$ & $\mathbf{P}^{3}$ & MS & $\mathbf{P}$ & MS & $\mathbf{P}$ & DF & MS & $\mathbf{P}$ & $\mathbf{R}^{2}$ \\
\hline Blocks & 2 & 0.31 & - & 0.68 & - & 1.11 & - & 6 & 1.01 & - & - \\
\hline Treatments & 29 & 2.09 & 0.001 & 3.27 & 0.001 & 1.42 & 0.023 & 29 & 5.23 & 0.001 & $47 \%$ \\
\hline Populations (P) & 27 & 0.71 & 0.138 & 1.91 & 0.001 & 0.69 & 0.604 & 27 & 1.79 & 0.001 & $15 \%$ \\
\hline General combining ability (GCA) & 7 & 0.92 & 0.101 & 4.58 & 0.001 & 0.89 & 0.341 & 7 & 3.32 & 0.001 & $7 \%$ \\
\hline Specific combining ability (SCA) & 20 & 0.64 & 0.241 & 0.98 & 0.090 & 0.63 & 0.682 & 20 & 1.25 & 0.011 & $8 \%$ \\
\hline Controls (C) & 1 & 32.67 & 0.001 & 24.00 & 0.001 & 13.50 & 0.001 & 1 & 68.06 & 0.001 & $21 \%$ \\
\hline $\mathrm{P} \times \mathrm{C}$ & 1 & 8.58 & 0.001 & 19.07 & 0.001 & 9.09 & 0.001 & 1 & 35.44 & 0.001 & $11 \%$ \\
\hline Years/Generations (YG) & - & - & & - & - & - & - & 2 & 6.43 & 0.001 & $4 \%$ \\
\hline Treat x YG & - & - & - & - & - & - & - & 58 & 0.77 & 0.164 & $14 \%$ \\
\hline $\mathrm{P} \times \mathrm{YG}$ & - & - & - & - & - & - & - & 54 & 0.76 & 0.178 & $13 \%$ \\
\hline GCA x YG & - & - & - & - & - & - & - & 14 & 1.53 & 0.004 & $7 \%$ \\
\hline SCA x YG & - & - & - & - & - & - & - & 40 & 0.50 & 0.812 & $6 \%$ \\
\hline $\mathrm{C} \times \mathrm{YG}$ & - & - & - & - & - & - & - & 2 & 1.06 & 0.191 & $1 \%$ \\
\hline$(P \times C) \times Y G$ & - & - & - & - & - & - & - & 2 & 0.65 & 0.359 & $0 \%$ \\
\hline Residue & 58 & 0.51 & - & 0.62 & - & 0.77 & - & 174 & 0.63 & - & $34 \%$ \\
\hline Total & 89 & & & - & - & - & - & 269 & - & - & - \\
\hline Overall mean & - & 3.5 & & 3.3 & & 3.0 & & - & 3.3 & - & - \\
\hline Mean of the populations & - & 3.4 & & 3.2 & & 2.9 & & - & 3.2 & - & - \\
\hline Mean of the susceptible control & - & 7.0 & & 7.0 & & 5.7 & & - & 6.6 & - & - \\
\hline Mean of the resistant control & - & 2.3 & & 3.0 & & 2.7 & & - & 2.7 & - & - \\
\hline $\mathrm{CV}(\%)^{4}$ & - & 20.3 & & 24.0 & & 29.4 & & - & 24.4 & - & - \\
\hline $\mathrm{SA}^{5}$ & - & 0.87 & & 0.90 & & 0.68 & & - & - & - & - \\
\hline
\end{tabular}

${ }^{1}$ Degrees of freedon; ${ }^{2}$ Mean Square; ${ }^{3}$ P-value; ${ }^{4}$ Coefficient of variation $(\%) ;{ }^{5}$ Selective Accuracy; $\mathrm{R}^{2}$ : Coefficient of Determination.

There was significance of GCA and of SCA, which indicates that the additive and non-additive effects act in control of the trait (Table 1). The coefficient of determination estimated for GCA and SCA was very similar, indicating that the two types of gene action are important. According to Cruz et al. (2012), in materials that underwent previous selection, as is the case of these parents, the differential for additive effects can be reduced, and the importance of the non-additive effects can increase, which explains the importance observed for SCA. GCA depends on additive variance, which is affected by the genetic diversity of the lines.

High general capacity ability for genotypes $\left(g_{i}\right)$ estimates (positive or negative) indicate better or worse genotypes than the mean behavior of the crosses (Ramalho et al., 1993). Only two lines exhibited $g_{i}$ estimates different from zero (CNFP 15867 and BRS Campeiro), based on combined analysis (Table 2). The line CNFP 15867 exhibited a positive $\mathrm{g}_{\mathrm{i}}$ estimate (0.39) and, for that reason, it is expected that the segregating 
populations in which this line participated as a parent exhibit a good reaction to fusarium wilt (Ramalho et al., 1993). Five populations in which CNFP 15867 participated as parent exhibited good reaction to fusarium wilt. This line should be recommended for use as a parent in new crosses, aiming at obtaining resistant cultivars.

Table 2. Estimates of general combining ability of the common bean parents $\left(g_{i}\right)$ for reaction to fusarium wilt in the winter/2012 $\left(\mathrm{F}_{3}\right)$, winter/2013 $\left(\mathrm{F}_{4}\right)$, and winter/2014 $\left(\mathrm{F}_{5}\right)$ crop seasons and in the mean, in Santo Antônio de Goiás, GO, Brazil.

\begin{tabular}{lcccc}
\hline \multirow{2}{*}{ Line } & \multicolumn{4}{c}{$\mathbf{g}_{\mathbf{i}}$} \\
\cline { 2 - 5 } & Mean & $\mathbf{F}_{\mathbf{3}}$ & $\mathbf{F}_{\mathbf{4}}$ & $\mathbf{F}_{\mathbf{5}}$ \\
\hline CNFP 15867 & $0.39^{*}$ & 0.39 & $0.35^{*}$ & 0.43 \\
CNFP 15868 & 0.17 & 0.28 & 0.18 & 0.04 \\
BRS Expedito & 0.15 & -0.11 & $0.46^{*}$ & 0.1 \\
CNFP 15869 & 0.02 & -0.06 & $0.35^{*}$ & -0.24 \\
BRS Esplendor & -0.04 & 0.06 & -0.1 & -0.07 \\
CNFP 15870 & -0.09 & -0.11 & 0.13 & -0.29 \\
CNFP 15871 & -0.15 & -0.22 & $-0.26^{*}$ & 0.04 \\
BRS Campeiro & $-0.44^{*}$ & -0.22 & $-1.10^{*}$ & -0.01 \\
\hline$\delta^{2}\left(\mathrm{~g}_{\mathrm{i}}\right)$ & 0.24 & - & 0.24 & - \\
$\delta^{2}\left(\mathrm{~g}_{\mathrm{i}}-\mathrm{gj}\right)$ & 0.36 & - & 0.36 & - \\
\hline$\delta^{2}(\mathrm{~g}), \mathrm{s}$ & & - & - & \\
\hline
\end{tabular}

$\delta^{2}\left(g_{i}\right)$, standard deviation associated with GCA effects; $\delta^{2}\left(g_{i}-g j\right)$, standard-deviation associated with contrasts among parents.

The cultivar BRS Campeiro exhibited a negative $\mathrm{g}_{\mathrm{i}}$ estimate (-0.44), contributing to an inferior performance for reaction to fusarium wilt. Five populations obtained from BRS Campeiro exhibited the worst reactions to fusarium wilt. In addition to these lines, others exhibited significant $\mathrm{g}_{\mathrm{i}}$ estimates only in the $\mathrm{F}_{4}$ generation, such as BRS Expedito (0.46), CNFP 15869 (0.35), and CNFP 15871 (-0.26).

Regarding specific capacity ability for each genotype $\left(\mathrm{s}_{\mathrm{ij}}\right)$, estimates equal to zero indicate that these populations exhibit reaction to fusarium wilt predicted by GCA, whereas non-zero estimates indicate that the behavior of a particular cross is better or worse than that expected based on GCA (Ramalho et al., 1993). Only two populations exhibited $\mathrm{s}_{\mathrm{ij}}$ other than zero (CNFP 15869 x CNFP 15868 and BRS Esplendor x BRS Campeiro) based on joint analysis (Table 3$)$, and both are negative $(-0.58)$, which indicates that these two crosses were relatively worse than expected, based on GCA.

The mean values of the populations ranged from 2.22 to 4.22 , confirming that there is genetic variability (Table 3). Even the population with the worst mean (BRS Esplendor $x$ BRS Campeiro) proved to be superior to the susceptible control (BRS Supremo), confirming the good resistance of the populations and the effectiveness of the parents. $32 \%$ of the populations exhibited reaction to fusarium wilt similar to that of BRS Esplendor (2.7a), the resistant control. The other populations exhibited scores from 3.1 to 4.2, which can be considered moderately resistant and with good possibilities for selection of resistant lines. The nine populations with greatest resistance to fusarium wilt were CNFP $15867 \mathrm{x}$ CNFP 15868, BRS Expedito x CNFP 15869, BRS Esplendor x CNFP 15868, BRS Esplendor x CNFP 15867, BRS Esplendor x BRS Expedito, CNFP 15870 x CNFP 15868, BRS Expedito x CNFP 15867, CNFP 15870 x CNFP 15867, and BRS Campeiro x CNFP 15867. Considering beyond the mean value, the presence of the parent that exhibited positive $g_{i}$ and the absence of the parent that exhibited negative $g_{i}$, the best populations for 
reaction to fusarium wilt were CNFP 15867 x CNFP 15868, BRS Esplendor x CNFP 15867, BRS Expedito x CNFP 15867, and CNFP 15870 x CNFP 15867. In addition to these, the populations CNFP 15871 x CNFP 15867 and CNFP 15869 x CNFP 15867 were moderately resistant to fusarium wilt and formed by the parent that exhibited positive $\mathrm{g}_{\mathrm{i}}$; these populations are still able to generate lines with good resistance.

Table 3. Mean values for reaction to fusarium wilt (FOP, score (1-9)), seed yield (YIELD, kg.ha ${ }^{-1}$ ), 100 seed weight $(100 \mathrm{SW}, \mathrm{g})$, and mean estimate of specific combining ability for each genotype $\left(\mathrm{s}_{\mathrm{ij}}\right)$ for reaction to fusarium wilt, evaluated in the winter/2012 $\left(\mathrm{F}_{3}\right)$, winter/2013 $\left(\mathrm{F}_{4}\right)$, and winter/2014 $\left(\mathrm{F}_{5}\right)$ crop seasons, of common bean segregating populations in Santo Antônio de Goiás, GO, Brazil.

\begin{tabular}{|c|c|c|c|c|c|c|c|}
\hline \multirow{2}{*}{$\begin{array}{l}\text { Population } \\
\text { CNFP } 15867 \text { x CNFP } 15868\end{array}$} & \multicolumn{2}{|c|}{ FOP } & \multirow{2}{*}{$\begin{array}{c}\mathbf{s}_{\mathrm{ij}} \\
0.38\end{array}$} & \multicolumn{2}{|c|}{ YIELD } & \multicolumn{2}{|c|}{$100 S W$} \\
\hline & 2.2 & $\mathrm{a}$ & & 2186 & $\mathrm{a}$ & 19.4 & $\mathrm{e}$ \\
\hline BRS Expedito x CNFP 15869 & 2.6 & $\mathrm{a}$ & 0.44 & 2032 & $\mathrm{~b}$ & 19.9 & $\mathrm{~d}$ \\
\hline BRS Esplendor x CNFP 15868 & 2.6 & $\mathrm{a}$ & 0.48 & 2272 & $\mathrm{a}$ & 18.2 & $\mathrm{f}$ \\
\hline BRS Esplendor x CNFP 15867 & 2.6 & $\mathrm{a}$ & 0.25 & 1887 & $\mathrm{~b}$ & 18.5 & $\mathrm{f}$ \\
\hline BRS Esplendor x BRS Expedito & 2.6 & $\mathrm{a}$ & 0.5 & 2212 & $\mathrm{a}$ & 21.1 & $\mathrm{c}$ \\
\hline BRS Esplendor & 2.7 & $\mathrm{a}$ & - & 2144 & $\mathrm{a}$ & 18.7 & $\mathrm{e}$ \\
\hline CNFP 15870 x CNFP 15868 & 2.8 & $\mathrm{a}$ & 0.31 & 2217 & $\mathrm{a}$ & 19.9 & d \\
\hline BRS Expedito x CNFP 15867 & 2.8 & $\mathrm{a}$ & -0.16 & 2270 & $\mathrm{a}$ & 20.5 & $\mathrm{c}$ \\
\hline CNFP 15870 x CNFP 15867 & 2.9 & $\mathrm{a}$ & -0.02 & 1997 & $\mathrm{~b}$ & 20.2 & d \\
\hline BRS Campeiro x CNFP 15867 & 3.0 & $\mathrm{a}$ & 0.22 & 2080 & $\mathrm{~b}$ & 20.7 & $\mathrm{c}$ \\
\hline CNFP 15871 x CNFP 15868 & 3.1 & $\mathrm{~b}$ & 0.03 & 2032 & $\mathrm{~b}$ & 19.0 & $\mathrm{e}$ \\
\hline CNFP 15871 x CNFP 15867 & 3.1 & $\mathrm{~b}$ & -0.19 & 2292 & $\mathrm{a}$ & 19.2 & $\mathrm{e}$ \\
\hline CNFP 15869 x CNFP 15870 & 3.1 & $\mathrm{~b}$ & 0.12 & 2037 & $\mathrm{~b}$ & 19.1 & $\mathrm{e}$ \\
\hline CNFP 15869 x CNFP 15871 & 3.1 & $\mathrm{~b}$ & 0.18 & 2095 & $\mathrm{~b}$ & 18.5 & $\mathrm{f}$ \\
\hline BRS Expedito x CNFP 15868 & 3.1 & $\mathrm{~b}$ & -0.27 & 1992 & $\mathrm{~b}$ & 20.5 & $\mathrm{c}$ \\
\hline BRS Campeiro x CNFP 15869 & 3.1 & $\mathrm{~b}$ & 0.47 & 1922 & $\mathrm{~b}$ & 20.1 & d \\
\hline CNFP 15871 x CNFP 15870 & 3.2 & $\mathrm{~b}$ & 0.18 & 2308 & $\mathrm{a}$ & 19.2 & $\mathrm{e}$ \\
\hline CNFP 15869 x CNFP 15867 & 3.2 & $\mathrm{~b}$ & -0.47 & 1997 & $\mathrm{~b}$ & 17.8 & $\mathrm{f}$ \\
\hline BRS Expedito x CNFP 15871 & 3.3 & $\mathrm{~b}$ & -0.17 & 2035 & $\mathrm{~b}$ & 20.9 & $\mathrm{c}$ \\
\hline BRS Esplendor x CNFP 15869 & 3.3 & $\mathrm{~b}$ & -0.16 & 2159 & $\mathrm{a}$ & 18.5 & $\mathrm{f}$ \\
\hline BRS Expedito x CNFP 15870 & 3.4 & $\mathrm{~b}$ & -0.34 & 2426 & $\mathrm{a}$ & 20.6 & $\mathrm{c}$ \\
\hline BRS Campeiro x BRS Expedito & 3.4 & $\mathrm{~b}$ & 0.01 & 2104 & $\mathrm{~b}$ & 23.3 & a \\
\hline CNFP 15869 x CNFP 15868 & 3.6 & $\mathrm{~b}$ & $-0.58 *$ & 2053 & $\mathrm{~b}$ & 17.9 & $\mathrm{f}$ \\
\hline BRS Campeiro x CNFP 15871 & 3.6 & $\mathrm{~b}$ & 0.2 & 2044 & $\mathrm{~b}$ & 20.4 & $\mathrm{c}$ \\
\hline BRS Esplendor x CNFP 15870 & 3.6 & $\mathrm{~b}$ & -0.27 & 1975 & $\mathrm{~b}$ & 19.2 & $\mathrm{e}$ \\
\hline BRS Esplendor x CNFP 15871 & 3.6 & $\mathrm{~b}$ & -0.21 & 2040 & $\mathrm{~b}$ & 18.9 & $\mathrm{e}$ \\
\hline BRS Campeiro x CNFP 15870 & 3.7 & $\mathrm{~b}$ & 0.03 & 2025 & $\mathrm{~b}$ & 21.8 & $\mathrm{~b}$ \\
\hline BRS Campeiro x CNFP 15868 & 3.8 & $\mathrm{~b}$ & -0.34 & 1966 & $\mathrm{~b}$ & 20.1 & $\mathrm{~d}$ \\
\hline BRS Esplendor x BRS Campeiro & 4.2 & $\mathrm{~b}$ & $-0.58 *$ & 2053 & $\mathrm{~b}$ & 20.9 & $\mathrm{c}$ \\
\hline BRS Supremo & 6.6 & $\mathrm{c}$ & - & 1698 & $\mathrm{~b}$ & 20.1 & $\mathrm{~d}$ \\
\hline$\delta^{2}(\mathrm{sij})$ & & & 0.53 & & & & \\
\hline$\delta^{2}(\mathrm{Sij}-\mathrm{Skl})$ & & & 0.73 & & & & \\
\hline$\delta^{2}(\mathrm{Sij}-\mathrm{Sik})$ & & & 0.81 & & & & \\
\hline
\end{tabular}

For seed yield, considering the three years/generations, the CVs ranged from 12.1 to $18.0 \%$, indicating good experimental accuracy (Table 4) (Pereira et al., 2008). The SA estimates were high $(0.70 \leq \mathrm{SA}<0.90)$ for the trials of the $\mathrm{F}_{4}$ and $\mathrm{F}_{5}$ generations and low $(\mathrm{SA}<0.50)$ for the trial of the $\mathrm{F}_{3}$ generation. In the $\mathrm{F}_{4}$ and $\mathrm{F}_{5}$ generations $(2013$ and 2014), there were significant differences, indicating that there is genetic variability among the 
treatments. The decomposition of the treatments of the individual analyses confirmed the existence of differences among the populations in the $\mathrm{F}_{4}$ and $\mathrm{F}_{5}$ generations.

\begin{tabular}{|c|c|c|c|c|c|c|c|}
\hline \multirow{2}{*}{ Source of variation } & \multirow{2}{*}{ DF } & \multicolumn{3}{|c|}{ Yield } & \multicolumn{3}{|c|}{100 seed weight } \\
\hline & & MS & $\mathbf{P}^{3}$ & $\mathbf{R}^{2}$ & MS & $\mathbf{P}$ & $\mathbf{R}^{2}$ \\
\hline Treatments & 29 & 191350 & 0.001 & 8 & 13.42 & 0.001 & 59 \\
\hline Populations (P) & 27 & 153219 & 0.011 & 6 & 14.00 & 0.001 & 57 \\
\hline Controls (C) & 1 & 895122 & 0.001 & 1 & 8.96 & 0.002 & 1 \\
\hline $\mathrm{P}$ vs $\mathrm{C}$ & 1 & 517117 & 0.014 & 1 & 2.32 & 0.103 & 0 \\
\hline Years/Generations (YG) & 2 & 19941347 & 0.001 & 56 & 15.43 & 0.020 & 5 \\
\hline Treatments x YG & 58 & 141962 & 0.005 & 12 & 1.13 & 0.097 & 10 \\
\hline Populations x YG & 54 & 147209 & 0.003 & 11 & 1.09 & 0.136 & 9 \\
\hline Controls x YG & 2 & 89681 & 0.344 & 0 & 0.87 & 0.365 & 0 \\
\hline$(\mathrm{P}$ vs $\mathrm{C}) \times \mathrm{YG}$ & 2 & 52578 & 0.534 & 0 & 2.46 & 0.060 & 1 \\
\hline Residue & 174 & 83628 & - & 20 & 0.86 & - & 26 \\
\hline Total & 269 & & - & - & - & - & - \\
\hline Overall mean & & 2085 & & & 19.77 & & \\
\hline Mean of the populations & & 2096 & & & 19.80 & & \\
\hline Mean of the controls & & 1921 & & & 19.43 & & \\
\hline $\mathrm{CV}(\%)^{4}$ & & 14 & & & 4.70 & & \\
\hline
\end{tabular}

${ }^{\mathrm{T}}$ Degrees of freedon; ${ }^{2}$ Mean Square; ${ }^{3} \mathrm{P}$-value; ${ }^{4}$ Coefficient of variation (\%); $\mathrm{R}^{2}$ : Coefficient of determination (\%).

Considering joint analysis, the decompositions of the treatments in populations and controls were significant, indicating the existence of differences among the genotypes within each one of these groups. The interaction among treatments and years/generations showed differential response, which is frequently reported in the literature (Pereira et al., 2017). Upon analyzing the importance of each source of variation of joint analysis, $8 \%$ of the total variation of the sum of squares was due to genetic variability. The importance of the YG effect $(56 \%)$ for seed yield was much greater than that estimated for reaction to fusarium wilt $(4 \%)$. For seed yield, this result was expected because it is considerably affected by the environment (Pereira et al., 2015; 2018).

The seed yield of the populations ranged from 1698 to $2426 \mathrm{~kg} / \mathrm{ha}^{-1}$, and $32 \%$ of the populations had seed yield similar to that of the best control, BRS Esplendor (Table 3). This indicates that there are populations with good yield performance. The nine populations with best performance showed mean values from 2426 to $2159 \mathrm{~kg} / \mathrm{ha}^{-1}$ : BRS Expedito x CNFP 15870, CNFP 15871 x CNFP 15870, CNFP 15871 x CNFP 15867, BRS Esplendor x CNFP 15868, BRS Expedito x CNFP 15867, CNFP 15870 x CNFP 15868, BRS Esplendor x BRS Expedito, CNFP 15867 x CNFP 15868, BRS Esplendor x CNFP 15869.

For 100 seed weight (100SW), the CVs ranged from $3.8 \%$ to $5.7 \%$, considering the trials of the three years/generations, showing excellent experimental accuracy. This was confirmed by the estimates of selective accuracy, considered high $(\mathrm{SA}>0.80)$ for the three years/generations (Pereira et al., 2017). There were significant differences $(\mathrm{P}<0.05)$ among the treatments in the three years/generations, indicating that there is genetic variability among the treatments. Considering joint analysis, the effect of treatments was also significant, confirming the difference between the genotypes within each one of these groups (Table 4). The significance of the years/generations factor indicates an important 
environmental effect, even with the evaluations having been made in the same location and crop season. The interactions between the treatments and the years/generations were not significant, indicating that behavior of the populations and controls coincided in the different years/generations, suggesting that there is no need to evaluate the populations in different years for this trait, which has otherwise been routinely reported (Faria et al., 2013). $59 \%$ of the total variation for 100 seed weight was due to genetic variability of the treatments, and only $5 \%$ of the total variation was due to the effect of years/generations, indicating that for this trait, just as for reaction to fusarium wilt, the genetic effect is more important compared to seed yield.

The mean value for 100 seed weight ranged from 17.8 to $23.8 \mathrm{~g}$ among the populations, and $36 \%$ of the populations had 100 seed weight superior to that of the controls BRS Supremo and BRS Esplendor (Table 3). The ten populations that had mean values superior to those of the controls were BRS Campeiro x BRS Expedito, BRS Campeiro $x$ CNFP 15870, BRS Esplendor x BRS Expedito, BRS Esplendor x BRS Campeiro, BRS Expedito x CNFP 15871, BRS Campeiro x CNFP 15867, BRS Expedito x CNFP 15870, BRS Expedito x CNFP 15868, BRS Expedito x CNFP 15867, and BRS Campeiro x CNFP 15871. Besides these, another five populations exhibited a mean value for 100 seed weight similar to that of the control BRS Supremo: CNFP 15870 x CNFP 15867, BRS Campeiro $x$ CNFP 15868, BRS Campeiro x CNFP 15869, BRS Expedito x CNFP 15869, and CNFP $15870 \times$ CNFP 15868 . These populations still have the possibility of generating lines with commercially acceptable bean seed size. Only six populations showed performance inferior to that of the controls.

As commented above, for a cultivar to be accepted by producers, it must join phenotypes desirable for various traits of interest. For that reason, it is important that these traits be considered throughout the process of development of lines, including evaluation and selection of segregating populations. Considering the mean values of reaction to fusarium wilt, yield, 100 seed weight, and presence of the parent CNFP 15867, which had a positive estimate of $\mathrm{g}_{\mathrm{i}}$, we identified a population with high resistance to fusarium wilt, high seed yield, and 100 seed weight superior to that of the controls, namely, BRS Expedito $x$ CNFP 15867. This population is the most promising for extraction of lines for obtaining cultivars. In addition to that population, the BRS Esplendor x BRS Expedito population should also be used because exhibited excellent results for reaction to fusarium wilt, yield, and 100 seed weight; even though the only line that presented high $\mathrm{g}_{\mathrm{i}}$ for fusarium wilt (CNFP 15867) is not one of their parents .

\section{ACKNOWLEDGMENTS}

To Embrapa Arroz e Feijão for funding this study. To FAPEG, for granting a master's degree scholarship to DGP. To the CNPq for granting a scholarship in research productivity in technological development and innovative extension to HSP, TLPOS, and LCM.

\section{CONFLICTS OF INTEREST}

The authors declare no conflict of interest. 


\section{REFERENCES}

Batista RO, Oliveira AMCE, Silva JLO, Nicoli A, et al. (2016). Resistance to Fusarium wilt in common bean. Crop Breed. Appl. Biotechnol. 16: 226-233.

Cândida DV, Costa JGC, Rava CA and Carneiro MS (2009). Controle genético da murcha do fusário (Fusarium oxysporum) em feijoeiro comum. Trop. plant pathol. 34: 379-384.

Cochran WG (1954). The combination of estimates from different experiments. Biometrics. 10: 101-129.

Costa JGC, Rava CA and Puríssimo JD (2007). Obtenção de linhagens de feijoeiro comum resistentes a murcha-defusário. Rev. Ceres. 54: 447-542.

Cruz CD (2013). Genes - a software package for analysis in experimental statistics and quantitative genetics. Acta Sci. Agron. 35: 271-276.

Cruz CD, Regazzi AJ and Carneiro PCS (2012). Modelos Biométricos aplicados ao melhoramento genético. Universidade Federal de Viçosa, Viçosa.

Faria LC , Melo PGS, Pereira HS, Peloso MJD, et al. (2013). Genetic progress during 22 years of improvement of carioca-type common bean in Brazil. Field Crops Res. 142: 68-74.

Ferreira LU, Melo PGS, Vieira RF, Lobo Júnior M, et al. (2018). Combining ability as a strategy to select common bean parents and populations resistant to white mold. Crop Breed. Appl. Biotechnol. 18: 276-283.

Gonçalves JGR, Chiorato AF, Silva DA, Esteves JÁF, et al. (2015). Combining ability in common bean cultivars under drought stress. Bragantia. 74: 149-155.

Griffing B (1956). Concept of general and specific combining ability in relation to diallel crossing system. Austr. J. Biol. Sci. 9: 463-493.

Mendes FF, Ramalho MAP and Abreu AFB (2009). Índice de seleção para escolha de populações segregantes de feijoeiro-comum. Pesqui. Agropecu. Bras. 44: 1312-1318.

Pastor-Corrales MA and Abawi GS (1987). Reactions of selected bean germ plasms to infection by Fusarium oxysporum f. sp. phaseoli. Plant Disease. 71: 990-993.

Pereira DG (2016). Melhoramento de feijoeiro-comum com grãos pretos para resistência à murcha-de-fusário. Master's degree thesis. Universidade Federal de Goiás, Goiânia. Available at [http://repositorio.bc.ufg.br/tede/handle/tede/7163].

Pereira HS, Alvares RCA, Silva FC, Faria LC, et al. (2017). Genetic, environmental and genotype x environment interaction effects on the common bean grain yield and commercial quality. Semina: Cienc. Agrar. 38: 1241-1250.

Pereira HS, Faria LC, Wendland A, Costa JGC, et al. (2018). Genotype by environment interaction for disease resistance and other important agronomic traits supporting the indication of common bean cultivars. Euphytica. 214: 12.

Pereira HS, Santos JB, Souza TP and Lima IA (2008). Seleção fenotípica e assistida por marcadores moleculares de famílias de feijoeiro-comum com alta produtividade. Pesqui. Agropecu. Bras. 43: 1551-1558.

Pimentel Gomes FP (2000). Curso de estatística experimental. Nobel. São Paulo.

Ramalho MAP, Abreu AFB. and Santos PSJ (1998). Interações genótipos x épocas de semeadura, anos e locais na avaliação de cultivares de feijão nas regiões Sul e Alto Paranaíba em Minas Gerais. Ciênc. Agrotec. 22: 175-181.

Ramalho MAP, Ferreira DF and Oliveira AC (2005). Experimentação em genética e melhoramento de plantas. Universidade Federal de Lavras. Lavras.

Ramalho MAP, Santos JB and Zimmermann MJ (1993). Genética quantitativa em plantas autógamas: aplicações ao melhoramento de feijoeiro. Universidade Federal de Goiás. Goiânia.

Rava CA, Sartorato A and Costa JGC (1996). Reação de genótipos de feijoeiro comum ao Fusarium oxysporum f. sp. Phaseoli em casa de vegetação. Fitopatol. Bras. 21: 296-300.

Resende MDV and Duarte JB (2007). Precisão e controle de qualidade em experimentos de avaliação de cultivares. Pesqui. Agropecu. Trop. 37: 182-194.

Rocha Júnior WC, Santos JB and Mendes Costa MC (1998). Reação de cultivares e linhagens de feijão à Fusarium oxysporum f. sp. phaseoli. Fitopatol. Bras. 23: 407-409.

Scott AJ and Knott M (1974). A cluster analysis method for grouping means in the analysis of variance. Biometrics. 30: 507-512.

Souza EDT, Silveira PM, Café Filho AC and Lobo Junior M (2012). Fusarium wilt incidence and common bean yield according to the preceding crop and the soil tillage system. Pesqui. Agropecu. Bras. 47: 1031-1037.

Souza TLPO de, Pereira HS, Faria LC de, Wendland A, et al. (2013). Cultivares de feijão comum da Embrapa e parceiros disponíveis para 2013. Embrapa Comunicado Técnico 2011. https://ainfo.cnptia.embrapa.br/digital/bitstream/item/97404/1/comunicadotecnico-211.pdf. Accessed 30 May 2019.

Vale NM, Barili LD, Oliveira HM, Carneiro JES, et al. (2015). Escolha de genitores quanto à precocidade e produtividade de feijão tipo carioca. Pesqui. Agropecu. Bras. 50: 141-148.

Zimmerman (2014). Estatística aplicada à pesquisa agrícola. Embrapa arroz e feijão. Santo Antônio de Goiás. 